\title{
Teaching complementary and alternative medicine in undergraduate medical education: a scoping review
}

\author{
Mary Soliman, Justin L. Bilszta
}

Department of Medical Education, Melbourne Medical School, University of Melbourne, Australia

Correspondence: Justin L. Bilszta, Department of Medical Education, Melbourne Medical School, University of Melbourne, Parkville, Australia. Email: jbilszta@unimelb.edu.au

\begin{abstract}
Objectives: This scoping review explores the extent to which undergraduate medical education have incorporated complementary and alternative medicine in their curricula and evaluates the teaching, delivery and assessment approaches used.

Methods: ERIC, Ovid Medline and Pubmed databases were searched with keywords related to "complementary and alternative medicine" and "undergraduate medical education" for relevant articles published until August 2020. Data extraction included the presence/absence of complementary and alternative medicine integration, program duration, instructor background, and assessment methods.

Results: Of 1146 citations, 26 met the inclusion criteria. Complementary and alternative medicine teaching in undergraduate medical education was widely inconsistent and not well aligned with clearly identified aims and objectives. Various complementary and alternative medicine disciplines were taught, demonstrated or observed, and several
\end{abstract}

programs included teaching on evidence-based medicine. Educational outcomes mainly assessed student satisfaction and learning through self-evaluation and rarely assessed for effectiveness with regards to changing clinical practice or impacts on patient outcomes.

Conclusions: Inconsistencies in complementary and alternative medicine teaching and assessment in undergraduate medical education reflect the lack of defined graduate competencies. An evidence-based medicine component of an educational program is a potential solution to overcoming breadth and content challenges. Curriculum developers would be better guided with research that determines if complementary and alternative medicine program design, content and assessment influence clinical practice and/or patient outcomes.

Keywords: Complementary and alternative medicine, undergraduate medical education, medical students, curriculum design, evidence-based medicine

\section{Introduction}

Medical educators encounter various challenges incorporating complementary and alternative medicine (CAM) teaching into undergraduate medical education (UGME). The term CAM relates to the use of non-mainstream practices, either together with conventional medicine (complementary), or in place of it (alternative). ${ }^{1}$ Common complementary health approaches include the broad descriptors of natural products (herbs, vitamins, minerals, probiotics), and mind and body practices (yoga, chiropractic, osteopathic manipulation, meditation, acupuncture, breathing exercises). In addition to the enormous breadth of CAM, there exists a degree of uncertainty around the validity and efficacy of many widely used therapies. ${ }^{2}$ Whereas conventional western medicine defines 'best practice' based on empirical trials utilising large patient populations, many CAM therapies boast an individualised approach where the practitionerpatient interaction is therapeutic rather than the therapy itself. ${ }^{2}$ This poses a considerable challenge for educators tasked with determining the necessary acquisition of CAM knowledge and skills in UGME.

Despite a need to upskill medical students in CAM-related knowledge and practice, there has not been an authoritative consensus regarding the acquisition of CAM skills and knowledge in medical students at graduation or the optimal method to provide this education. This raises the question as to what evidence and scholarship can curriculum developers

140

(C) 2021 Mary Soliman \& Justin L. Bilszta. This is an Open Access article distributed under the terms of the Creative Commons Attribution License which permits unrestricted use of work provided the original work is properly cited. http://creativecommons.org/licenses/by/3.0 
draw upon to plan and implement CAM curricula for UGME students? A preliminary search of the literature, whilst failing to identify any reviews which have systematically investigated CAM teaching in UGME curricula, did provide some insight into the challenges (and innovations) medical schools face in teaching and assessing student learning related to CAM practices. Stratton and Colleagues (2007) surveyed CAM educational programs funded by the National Center for Complementary and Alternative Medicine (NCCAM). They found an array of curricula exist to provide health professions students with the necessary knowledge, attitudes, and skills to address CAM-related issues, and the approaches to evaluating curricular efforts were equally diverse; limiting the survey to only those that received NCCAM funding means it is difficult to generalise the findings. ${ }^{3}$ The second attempted to systematically evaluate evidence of effective CAM educational interventions for both biomedical doctors and medical students. ${ }^{4}$ This review only focused on descriptions of randomized controlled trials (RCTs), nonrandomized controlled trials (non-RCTs), and before and after studies. Importantly, it did not specifically examine descriptions of integrating CAM materials in the broader context of UGME curricula, nor did it explore the variety of teaching, learning and assessment approaches UGME programs utilise. This latter issue is of particular interest as it is important to determine if there is a correlation between changes in student's CAM-related attitudes, knowledge, skills and the provision of patient care.

We, therefore, conducted this scoping review of primary studies to evaluate the different approaches UGME programs have taken to incorporate CAM teaching into their curricula and identify directions for future research. The specific research questions we sought to answer were: 1. do UGME programs teach students about CAM and, if so, which CAM disciplines do UGME programs teach students? 2. what teaching and learning approaches do UGME use to teach students about CAM? and; 3. how are UGME students assessed about their knowledge of CAM? In addition to these questions, this review also evaluated the effectiveness of CAM teaching in the included studies, using the Kirkpatrick Hierarchy for Assessing Educational Outcomes.-7

\section{Methods}

This study adopted the "Preferred Reporting Items for Systematic reviews and Meta-Analysis extension for Scoping Reviews" (PRISMA-ScR) reporting protocol. ${ }^{8}$

\section{Search Strategy}

Electronic databases ERIC, Ovid Medline and PubMed were searched for full-text articles describing the delivery of CAM teaching in UGME (see Table 1). Additional papers were found through a hand search of the reference lists of articles identified through the online database search.

\section{Inclusion and Exclusion Criteria}

There was no limit on the publication date. Only full-text articles written in English were included. Articles were limited to those that looked exclusively at UGME, with medical students only. Articles exploring medical students' or faculty members' attitudes regarding CAM were excluded. Articles that did not clearly describe the characteristics of CAM teaching within the UGME curricula (for example, topics taught in CAM programs, duration or frequency of teaching programs, methods used to assess student learning, etc.) were also excluded, as were general articles about CAM in medical education, and proposals for CAM curricula without implementation and opportunity for subsequent evaluation.

Table 1. Keyword search strategy with combined search terms

\begin{tabular}{|c|c|}
\hline No & Keyword Search Strategy \\
\hline 1 & $\begin{array}{l}\text { (Complementary and alternative medicine or CAM or comple- } \\
\text { mentary medicine or alternative medicine or homeopath* or } \\
\text { naturopath*) }\end{array}$ \\
\hline 2 & $\begin{array}{l}\text { (Medical school or medical education or education or teach* or } \\
\text { undergraduate medical or curricul* or course }{ }^{\star} \text { ) }\end{array}$ \\
\hline 3 & 1 and 2 \\
\hline 4 & $\begin{array}{l}\text { (Medical school or medical education or medical program or } \\
\text { medical curricul* medical course* or undergraduate medical or } \\
\text { cirricul* }^{*} \text { or course }{ }^{\star} \text { ) }\end{array}$ \\
\hline 5 & 1 and 4 \\
\hline
\end{tabular}

\section{Key terms and Boolean Operators}

Complementary and alternative medicine, CAM, complementary medicine or alternative medicine, homeopath*, Chinese medicine, undergraduate medical, medical school, medical education, medical course, medical cirricul ${ }^{\star}$, teach, university.

\section{Data Extraction and Charting}

Data extraction was performed using a predetermined list, and included:

- Article details: first author and publication year

- Participant information: student cohort, institution, or country/city of institution

- Information gathering approach: questionnaire, survey, telephone interview

- Educational intervention: presence or absence of CAM integration, topics taught in CAM programs

- Duration or frequency: time spent delivering teaching within the program

- Instructors background: qualifications or title of educators

- $\quad$ Outcome assessment: methods used to assess program aims, primarily students' qualitative and quantitative course evaluation

- Educational outcome: assessed using Kirkpatrick's Hierarchy of Educational Outcomes, a well-recognised tool for the evaluation of the effectiveness of medical, educational outcomes. ${ }^{5-7}$ The bottom level 
assesses learners' satisfaction with, or reaction to, the Intervention; the second level assesses modification of students' attitudes and perceptions and/or the knowledge and skills learned; the third level assesses changes in health professionals' behaviour or an institution's practice, and; at the top of the hierarchy, changes in patient health care outcomes. In this review, Kirkpatrick's Hierarchy was used to assess educational interventions as they relate to specific CAM programs taught within UGME curricula.

\section{Limitations: identified program limitations}

\section{Synthesis of Results}

Each of the included studies was described by the author, year of publication, and the characteristics listed above. Thematic analysis was conducted to identify commonalities between the included studies. No inferences were made about CAM teaching, learning, and assessment approaches if they were not explicitly stated. Literature searching, title and abstract screening, full-text review and data extraction and charting were undertaken by the first author (MS). Where there was any uncertainty regarding the aforementioned, these articles were reviewed independently by the 2 nd author (JB) and then discussed until consensus was reached between both authors. The 2nd author also independently reviewed the data extraction and charting results once this process was completed by the first author.

\section{Results}

The primary search, which was conducted between July-September 2020, yielded 1146 citations - 960 citations from PubMed, 32 from Medline and 154 from ERIC. After the removal of duplicate citations and those not written in English, 1127 remained. Following a review of titles and abstracts, 113 fulltext articles remained, of which 26 met the inclusion criteria. See Figure 1 for the complete search and study selection strategy. A summary of the included studies is found in Table 2 and Table 3. Two main categories of literature were identified: 1 . those reporting whether CAM was included in a medical school's UGME curricula, and; 2. those describing the teaching, learning and assessment approaches implemented in UGME.

\section{Is CAM Being Taught in UGME?}

Ten studies directly addressed the inclusion of CAM in UGME curricula (see Table 2). Seven studies ${ }^{9-15}$ utilised written questionnaires or surveys to collect program information, whilst two ${ }^{16,17}$ used a telephone interview, and one ${ }^{18}$ used a combination of both. Sampson and Colleagues ${ }^{13}$ and Brokaw and Colleagues ${ }^{10}$ assessed CAM education in U.S. medical schools. Sampson and Colleagues reported $45 \%$
(56/125) of medical schools offered some form of CAM education. Brokaw and Colleagues reported of 53 U.S medical schools surveyed, $75.3 \%$ (40/53) taught an elective CAM course, and $30.1 \%(16 / 53)$ taught a required course, with several schools (7/53) offering both. In neighbouring regions of North America, Ruedy and Colleagues ${ }^{17}$ found of the $16 \mathrm{Ca}$ nadian medical schools evaluated, $81 \%$ (13/16) reported the inclusion of CAM in their medical programs, and the remaining 19\% (3/16) were planning to include CAM teaching in the future. Rampes and Colleagues ${ }^{12}$ survey of British medical schools reported only 3 of 24 schools (12.5\%) offered CAM teaching, and none provided practical training. Smith $^{14}$ found CAM was included in the curricula of all 18 responding UK medical schools (58\% response rate), with $33.3 \%(6 / 18)$ indicating it was taught formally within the UGME curriculum.

In Europe, Brinkhaus and Colleagues ${ }^{9}$ surveyed 487 department directors at medical schools in Austria, Germany and Switzerland. Of these, 34\% (162/487) indicated CAM had been integrated into their medical schools' curricula. There was noted inter-country variability with lower CAM integration in Switzerland (20\%) compared to Austria (28\%) and Germany (27\%). Varga and Colleagues ${ }^{15}$ surveyed 265 medical faculties in European medical schools, reporting that $40 \%$ of responding universities offer some form of CAM teaching. In Japan, Tsuruoka and Colleagues ${ }^{18}$ reported CAM teaching was included in 16 of 80 (20\%) schools, with 19 different teaching and learning approaches described. Kim and Colleagues (2012) reported CAM was taught at $85.4 \%$ (35/41) of participating Korean medical schools. ${ }^{11}$ Chitindingu and Colleagues ${ }^{16}$ survey of seven South African schools reported one school was teaching both Traditional Medicine (T.M.) and CAM, five were teaching either T.M. or CAM, and one was teaching neither. T.M. relates to therapeutic practices that incorporate plant, animal and mineralbased medicines, spiritual therapies, manual techniques and exercises, often practiced in developing countries. ${ }^{19}$ Whilst TM is regarded as distinct from CAM, TM practices may be included within CAM. ${ }^{20}$

Data on what elements of CAM are taught in UGME was inconsistently reported. In general, of studies that looked at whether CAM was taught in UGME, acupuncture was the most frequently taught modality ${ }^{11,12,17,18}$ followed by homeopathy ${ }^{10-12,17}$ and manipulation or chiropractic therapies. ${ }^{10,12}$ In studies evaluating how implemented CAM programs are taught, the most commonly taught or demonstrated CAM disciplines were acupuncture $\mathrm{e}^{21-25}$ manipulation/chiropractic 24,26, 27 and massage. ${ }^{21-23}$ Less frequently taught therapies included biofeedback ${ }^{21,26}$ nutrition $^{21,28}$ analysis of medicinal plants ${ }^{24}$ homeopathy ${ }^{26,27}$ hypnosis ${ }^{26}$ and osteopathy. ${ }^{27}$ Several of the identified programs taught about the evidence base of CAM alongside the risks and benefits or offered an opportunity for scientifically evaluating CAM efficacy. ${ }^{21,24,27,29-32}$ 


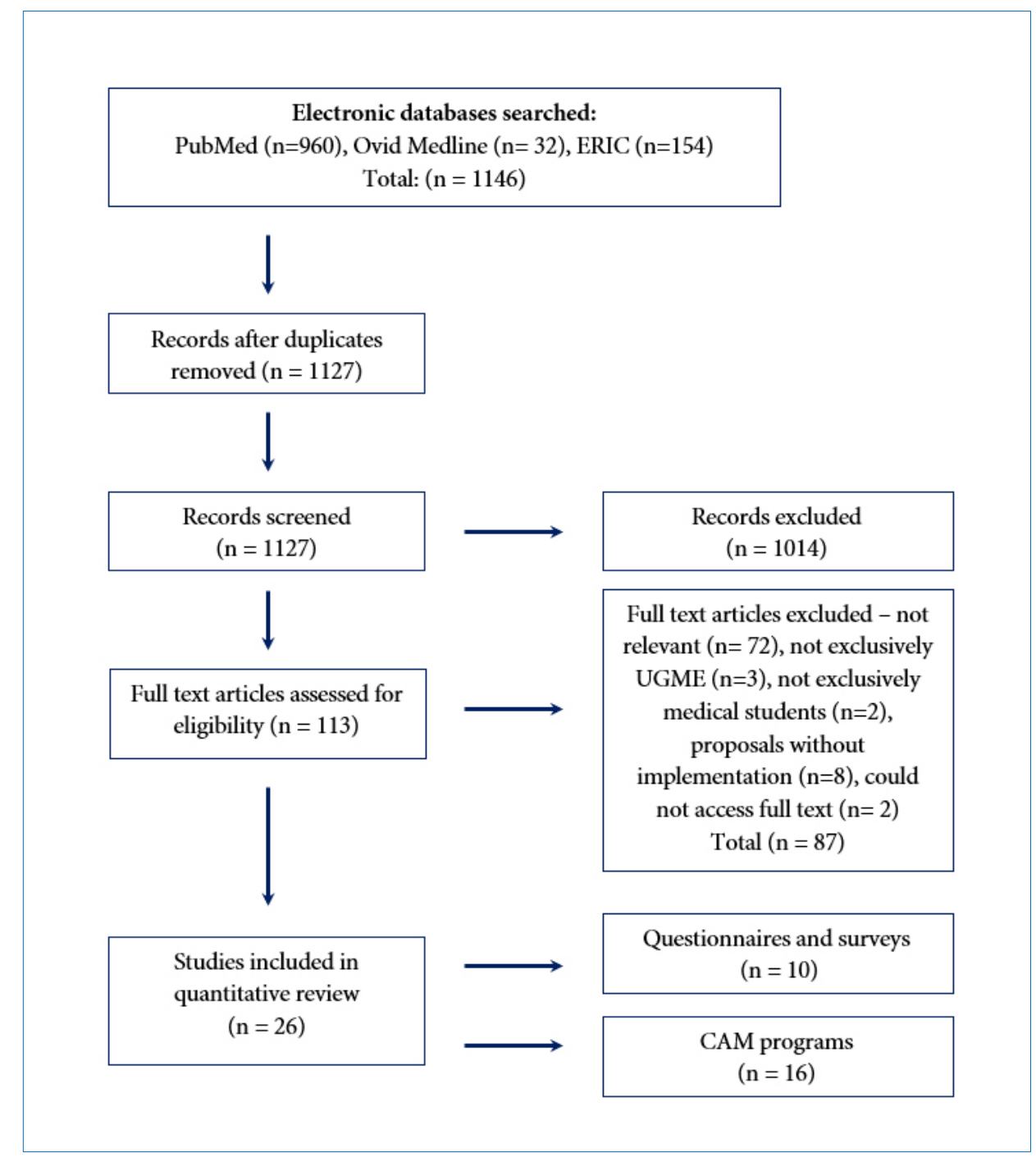

Figure 1. PRISMA Diagram

\section{How is CAM Taught in UGME?}

Sixteen articles ${ }^{21-30,32-37}$ described specific CAM teaching, learning, and assessment approaches in UGME curricula. A detailed breakdown of the different approaches used is described in Table 3. The structure of teaching modules varied greatly between programs. In a unique approach, Da Silva and Colleagues ${ }^{22}$ reported a split teaching program, where students attended CAM classes in their third year, followed by clinical placements in their fifth year. Meanwhile, other programs included integrated CAM teaching across three ${ }^{28}$ four ${ }^{24,34}$ five $^{30}$ and six years ${ }^{25}$ of their UGME programs. Other programs adopted a block approach, where teaching was delivered over a period of weeks to months. ${ }^{27-29,31,35,36}$

Teaching time also varied greatly across institutions. Duration of time ranged from a relatively brief 5 hours $^{21}$, to the longest of 90 hours. ${ }^{25}$ Several of the programs with integrated teaching across several years did not report on the total teaching time, including Frenkel and Colleagues ${ }^{34}$ and
Perlman and Stagnaro. ${ }^{24}$ The teaching modalities used in the delivery of CAM education varied widely. Only one program $^{24}$ used a solely didactic approach. Others used a didactic approach in conjunction with some form of interactive teachings such as tutorials ${ }^{24,30}$ hands-on practice ${ }^{23}$ discussion-based learning ${ }^{31,35,36}$ workshop ${ }^{34}$ case and team-based learning ${ }^{28}$ or student-led presentations. ${ }^{35}$ In a commonly utilised approach, several programs included a clinical placement in combination with formal lectures or tutorials..$^{22,25-28,31}$ These placements varied in length from one $\mathrm{day}^{26}$ to four-afternoon sessions of unspecified duration ${ }^{22}$ to 30 hours. ${ }^{25}$ Bailey and Colleagues ${ }^{21}$ reported a unique approach involving a seminar followed by an Integrative Medicine fair where over 30 providers interacted with students through a series of student-selected workshops that introduced fields such as nutrition, massage, acupuncture, yoga and biofeedback. Similarly, the program described by Lehmann and Colleagues ${ }^{35}$ offered a unique one-day excursion to the European Library for Homeopathy (Kothen, Germany). 
Soliman \& Bilszta CAM in undergraduate medical education

Table 2. Is CAM being taught in UGME?

\begin{tabular}{|c|c|c|}
\hline Reference & Participants & Information Gathering Approach \\
\hline $\begin{array}{l}\text { Brinkhaus and } \\
\text { Colleagues } \\
2011^{9}\end{array}$ & $\begin{array}{l}\text { 1,017 department directors } \\
\text { at medical schools in Aus- } \\
\text { tria, Germany, and Switzer- } \\
\text { land. } 487 \text { questionnaires } \\
\text { (response rate: } 48 \% \text {, coun- } \\
\text { try-specific response rate: } \\
\text { A 39\%; G } 49 \% \text {; S 42\%) } \\
\text { were returned. }\end{array}$ & Standardised questionnaire \\
\hline $\begin{array}{l}\text { Brokaw } \\
\text { and Colleagues } \\
2002^{10}\end{array}$ & $\begin{array}{l}123 \text { CAM course directors } \\
\text { at } 74 \text { U.S. medical schools. } \\
\text { Questionnaires were } \\
\text { returned by } 73 \text { course } \\
\text { directors at } 53 \text { schools. }\end{array}$ & $\begin{array}{l}\text { Questionnaires mailed to course } \\
\text { directors. The } 2 \text { page question- } \\
\text { naire consisted of nine ques- } \\
\text { tions with a check-box or fill-in- } \\
\text { the-blank format, and one space } \\
\text { at the end for written comments. }\end{array}$ \\
\hline
\end{tabular}

Chitindinguand

Colleagues

$2014^{16}$

Kim

and Colleagues

$2012^{11}$

Rampes

and Colleagues

$1997^{12}$

Ruedy and Colleagues

$1999^{17}$

Smith

$2011^{14}$

Tsuruoka and Colleagues $2001^{18}$

Varga and Colleagues $2006^{15}$
Heads of School from seven South African medical schools

Academic or curriculum deans and faculty at each of 41 Korean medical schools. Replies were received from all 41 schools.

24 of 26 Deans of British medical schools responded

16 Canadian undergraduate medical schools deans or faculty members.

Survey of 125 U.S. medical schools

Deans of U.K. Undergradu- Survey ate Medical Schools. The overall response rate was $58.1 \%(18 / 31)$.
Questionnaire to learn of approaches to CAM in curricula.

A mail survey was conducted from 2007 to 2010 .

\section{Questionnaire}

Telephone interview lasting approximately 30 minutes was conducted with most respondents.

62 respondents (34\%) indicated that CAM therapies had already been integrated into the curriculum (treatment $26 \%$, research $19 \%$ and education $18 \%$ ) with no significant differences between the countries. Respondents of Switzerland indicated lower activity of CAM integration (treatment $10 \%$ and research $10 \%$ ) compared to Austria $(28 \%, p=0.016$ and $28 \%, p=0.016)$ and Germany $(27 \%$, $p=0.01$ and $20 \%, p=0.174)$

$75.3 \%(40 / 53)$ taught an elective CAM course, and $30.1 \%(16 / 53)$ taught a required course. Topics most often being taught were acupuncture $(76.7 \%)$, herbs and botanicals $(69.9 \%)$, meditation and relaxation $(65.8 \%)$, spirituality/faith/prayer $(64.4 \%)$, chiropractic $(60.3 \%)$, homeopathy $(57.5 \%)$, and nutrition and diets $(50.7 \%)$. Amount of instructional time varied widely, but most received about two contact hours. The "typical" CAM course an elective, was most likely to be taught in the first or fourth year of medical school, and had fewer than 20 contact hours of instruction. Most of the courses $(78.1 \%)$ were taught by practitioners or prescribers of CAM therapies. Few of the courses (17.8\%) emphasized a scientific approach to the evaluation of CAM effectiveness.

One school was teaching both Traditional African Medicine (T.M.) and CAM, five were teaching either T.M. or CAM and another was not teaching any aspect of TCAM. Conclusion: Medical schools have not responded to government policies or contextual realities by incorporating TCAM into the curriculum for their students.

CAM was taught at 35 schools (85.4\%). Most common courses were introduction to CAM or integrative medicine (88.6\%), traditional Korean medicine $(57.1 \%)$, homeopathy and naturopathy $(31.4 \%)$, and acupuncture $(28.6 \%)$

Of 24 medical schools, 3 were offering teaching, and none were providing practical training. Acupuncture is included in the curricula of all three of these schools, and hypnosis, homoeopathy, manipulation and therapeutic massage in two.

Most schools reported that they include CAM in their curricula (13/16), usually as part of a required course. Lectures constitute the most frequent method of information delivery, predominantly during the preclinical years. Acupuncture (in 10 schools) and homeopathic medicine (in 9 schools) were the interventions most often included. Only 2 schools reported that they provide instruction on the actual practice of one or more complementary therapies.

Of the 56 schools that had some form of relevant course offering, only nine had invited critical lecturers on occasion; their courses were otherwise generally supportive of CAM. Two course directors claimed to present information "neutrally," but did not teach critical methods or invite critical lecturers. Only four courses either presented a critical orientation or offered critical arguments in a way that significantly investigated advocacy arguments.

All respondents indicated that their curricula included CAM elements. However, the quantity of CAM within curricula varied widely between medical schools, as did the methods by which CAM education was delivered. General Medical Council requirements were the strongest factor influencing the inclusion of CAM, although medical student preferences were also important. Respondents were generally satisfied with the extent of CAM provision within their curricula, while a wide range of views on the appropriateness of CAM in the medical curriculum were held by faculty members.

1. A telephone survey to curricu- Of 80 medical schools, CM was officially taught in 16 schools (20\%). lar office workers in September Of these 16 schools, there were $19 \mathrm{CM}$ courses and the anesthesia

80 Japanese medica schools for Western medicine. Response rate to the telephone survey and self-completed questionnaire was 100 and $95 \%$, respectively.

2. A self-completed questiondepartment sponsored the most courses (six courses). All courses had oriental medicine titles such as acupuncture and Kampo except naire to representatives of spon- for one course. soring departments

Questionnaire of 7 questions concerning CAM education in their establishments.
Only $40 \%$ of the responding universities were offering some form of CAM training. Could not show any correlation between the public demand for CAM methods and the availability of CAM training in medical universities. 
Generally, the instructors delivering CAM programs were either faculty members of the medical school or clinicians $^{29,30,34-36}$ external CAM practitioners only ${ }^{26,31}$ or both. ${ }^{21,24,25,27,32}$ Several programs also included visiting experts and scholars from other universities. ${ }^{24,28}$ In some instances, faculty members were noted to have undergone advanced CAM training. ${ }^{24,32}$ Several programs involved qualified community or student CAM providers and practitioners, including those with an element of clinical placement. ${ }^{21,23,26,27,31}$ Post course student evaluations were infrequently used to assess student experiences and overall course satisfaction. ${ }^{26,31} \mathrm{Ob}$ jective assessment of knowledge and learning was not performed. Where knowledge assessment was completed, it often entailed subjective self-reporting using a Likert scale or other quantitative measure..$^{22,23,27-29,36} \mathrm{Few}$ programs used appropriately coded and thematically interpreted qualitative measures. ${ }^{34,35}$ Several programs did not have formal evaluative or assessment processes in place $e^{24,25,30,37}$ or removed the evaluative process following a period of time. ${ }^{21}$

\section{Assessment of Education and Learning Outcomes}

This review assessed the educational and learning outcomes of the aforementioned studies using Kirkpatrick's Hierarchy (Table 2). ${ }^{5-7}$ There was a clear trend toward Level 1 outcomes, where student reaction and satisfaction were measured in all programs, bar one $\mathrm{e}^{34} \mathrm{using}$ a post-course evaluation. Likewise, a majority of programs achieved Level 2 outcomes by considering the achievement of learning outcomes by students who completed self-evaluations..$^{21,22,27-29,32,34-36}$ Only Frenkel and Colleagues $^{34}$ achieved Level 3 outcomes, where students were asked if and how learned knowledge from the CAM program would change their behaviour. It should be noted behavioural changes were self-reported and not directly observed or analysed. Level 4 outcomes were not achieved by any of the UGME programs included in this review.

\section{Discussion}

This scoping review of CAM education in UGME demonstrates the emerging interest in this area. In view of the rising use of CAM and the potential for CAM-conventional therapy interactions, there is an increasing need for physicians to become familiar with common CAM therapies. ${ }^{38}$ As reported, past and current inclusion of CAM teaching, even within schools located in the same country, is inconsistent. In curricula that include CAM, teaching and learning vary widely, both in terms of content and delivery. It appears agreed statements on the expected skills and competencies of medical students at graduation related to CAM therapies are yet to emerge. In the absence of this consensus, it is difficult to identify clear aims and objectives of any CAM teaching program within a medical course. The following discussion amalgamates the key findings and addresses their implications, with the overall aim of aiding in the development of consistent and equitable medical education.

\section{Program Format and Design}

The duration of teaching is one of the greatest areas of inconsistency amongst the included programs. Whilst a number had integrated CAM teaching across one or several years of their curriculum, the design of others was relatively brief, with few - or unspecified - dedicated teaching hours. ${ }^{21,32,37}$ Meanwhile, several 'integrated' programs regarded the practices of mindfulness and self-care for students as an element of their holistic CAM curriculum. ${ }^{23,30}$ Other medical schools considered mentioning CAM in areas of relevance - such as drug interactions and clinical oncology - constituted sufficient CAM teaching. ${ }^{14}$ This could lead to a potentially inflated and inaccurate measure of the duration of CAM teaching, particularly within these integrated approaches.

In analysing the approach to teaching, it is clear experiential learning is favoured compared to a solely didactic approach. Nearly all programs favoured delivery methods that would enhance student engagement. These included tutorials, workshops and case discussions, alongside clinical placements with CAM practitioners. Whilst well received by students, most immersive methods only achieved Kirkpatrick's Level 1 and/or 2 outcomes, without an assessment of translatability to clinical practice and impacts on patient outcomes, which would require Level 3 and 4 outcomes, respectively. Various programs included clinical placements with CAM practitioners, the longest being 30 hours. ${ }^{25}$ However, in the absence of a student evaluation or objective assessment tool, the benefits of clinical placement cannot be commented on.

Various programs focussed on specific CAM disciplines, the most common of which was acupuncture. ${ }^{21-25}$ This reflects the identified difficulties in establishing a discrete knowledge base, as CAM disciplines require constant updating as new evidence and novel therapies emerge and gain traction within the general population. ${ }^{3}$ In what proved to be a popular approach ${ }^{21,24,27,29-32}$ analysis of the evidence base surrounding CAM is one of the more common methods of teaching. In equipping students with the skill set needed to critically appraise evidence, the plethora of CAM therapies need not be delved into individually. Rather, students can draw their own informed conclusions without the influence of potentially biased and unsubstantiated claims. Despite this, not all programs included teaching on evidence-based medicine (EBM), rather focusing on specific CAM disciplines. In designing a sustainable CAM program, curriculum developers should consider the need for constant review and critical appraisal as new evidence emerges. The EBM teaching model presents a potential solution to a rather overwhelming and resource intensive area of education, where learned knowledge and skills can be adapted for differing CAM modalities, and beyond. 
Soliman \& Bilszta CAM in undergraduate medical education

Table 3. How is CAM taught in UGME?

\begin{tabular}{|c|c|c|c|c|c|c|c|}
\hline Reference & Participants & $\begin{array}{l}\text { Education Approach/ } \\
\text { Intervention }\end{array}$ & $\begin{array}{l}\text { Duration and fre- } \\
\text { quency }\end{array}$ & $\begin{array}{l}\text { Instructors } \\
\text { background }\end{array}$ & $\begin{array}{l}\text { Outcome } \\
\text { measure }\end{array}$ & Outcomes Assessment & Limitations \\
\hline $\begin{array}{l}\text { Bailey } \\
\text { and } \\
\text { Colleagues } \\
2015^{21}\end{array}$ & $\begin{array}{l}\text { Fourth year } \\
\text { medical } \\
\text { students at } \\
\text { Duke } \\
\text { University, } \\
\text { USA }\end{array}$ & $\begin{array}{l}\text { Initially a 90-minute interac- } \\
\text { tive seminar providing intro- } \\
\text { ductory core } \\
\text { learning. This developed } \\
\text { into a seminar and I.M. fair. } \\
\text { Included I.M. fields were nu- } \\
\text { trition, massage, } \\
\text { acupuncture, yoga and } \\
\text { biofeedback. The program } \\
\text { changed over time from as- } \\
\text { signed to student } \\
\text { selected teaching modali- } \\
\text { ties. }\end{array}$ & $\begin{array}{l}1 \text { hour seminar + } \\
4 \text { hour fair during } \\
\text { which each stu- } \\
\text { dent attended } 4 \\
\text { x } 40 \text { minute } \\
\text { workshops. } \\
\text { This structure } \\
\text { was adapted and } \\
\text { repeated from } \\
2005 \text {-2013 }\end{array}$ & $\begin{array}{l}\text { Duke } \\
\text { University } \\
\text { faculty, staff } \\
\text { and commu- } \\
\text { nity CAM } \\
\text { providers }\end{array}$ & $\begin{array}{l}1,2 a, 2 b \text {, } \\
3\end{array}$ & $\begin{array}{l}\text { Qualitative and descriptive data } \\
\text { from course evaluations com- } \\
\text { pleted by students, and quantita- } \\
\text { tive data from the AAMC gradu- } \\
\text { ate questionnaire. Pre and post } \\
\text { knowledge testing was com- } \\
\text { pleted for an unspecified period } \\
\text { of time, then removed. }\end{array}$ & $\begin{array}{l}\text { Removal of } \\
\text { pre-post } \\
\text { knowledge } \\
\text { testing }\end{array}$ \\
\hline $\begin{array}{l}\text { da Silva } \\
\text { and } \\
\text { Colleagues } \\
2013^{22}\end{array}$ & $\begin{array}{l}\text { Third and fifth } \\
\text { year medical } \\
\text { students at Rio } \\
\text { Preto Medical } \\
\text { School. Brazil }\end{array}$ & $\begin{array}{l}\text { Third year students receive } \\
\text { acupuncture classes as part } \\
\text { of their formal curriculum. } \\
\text { Fifth year students attend } \\
\text { acupuncture outpatient clin- } \\
\text { ics }\end{array}$ & $\begin{array}{l}\text { Third year: } 6 \\
\text { hours of } \\
\text { classes } \\
\text { Fifth year: } 4 \mathrm{x} \text { af- } \\
\text { ternoon sessions } \\
\text { in clinic }\end{array}$ & Not specified & $\begin{array}{l}1,2 a, 2 b, \\
3\end{array}$ & $\begin{array}{l}5 \text { question, } \\
1-5 \text { scale evaluation completed } \\
\text { by } 2011 \text { and } 2012 \text { cohort. Sub- } \\
\text { jective assessment of } \\
\text { knowledge and likelihood of } \\
\text { identifying when CAM is suitable } \\
\text { for patients. }\end{array}$ & $\begin{array}{l}\text { Lack of objec- } \\
\text { tive measure of } \\
\text { knowledge or } \\
\text { skills }\end{array}$ \\
\hline $\begin{array}{l}\text { Forjuoh } \\
\text { and } \\
\text { Colleagues } \\
2003^{29}\end{array}$ & $\begin{array}{l}\text { Third year } \\
\text { medical stu- } \\
\text { dents of a } \\
\text { state, public } \\
\text { medical school } \\
\text { in Texas, USA }\end{array}$ & $\begin{array}{l}\text { Interactive educational ses- } \\
\text { sions on family } \\
\text { medicine, with CAM teach- } \\
\text { ing integrated within. In ad- } \\
\text { dition, EBM was taught as a } \\
\text { tool to teach CAM, enabling } \\
\text { students to critically } \\
\text { appraise therapies for their } \\
\text { safety and efficacy in clini- } \\
\text { cal practice. }\end{array}$ & $\begin{array}{l}5 \text { hour clerkship } \\
\text { session } \times 6 \\
\text { weeks }\end{array}$ & $\begin{array}{l}\text { Faculty mem- } \\
\text { bers including } \\
\text { the director of } \\
\text { research and } \\
\text { a family phy- } \\
\text { sician }\end{array}$ & $1,2 a, 2 b$ & $\begin{array}{l}\text { Likert scale and Wilcoxon signed } \\
\text { rank test used in a pre and post- } \\
\text { curriculum questionnaire evalu- } \\
\text { ating changes in students per- } \\
\text { ceived knowledge, attitudes, and } \\
\text { skills. }\end{array}$ & $\begin{array}{l}\text { Lack of objec- } \\
\text { tive measure of } \\
\text { knowledge or } \\
\text { skills, and } \\
\text { small sample } \\
\text { size, further re- } \\
\text { duced by } 19 \% \\
\text { that did not } \\
\text { complete the } \\
\text { evaluation. }\end{array}$ \\
\hline $\begin{array}{l}\text { Frenkel } \\
\text { and } \\
\text { Colleagues } \\
2007^{34}\end{array}$ & $\begin{array}{l}4 \text { graduates } \\
\text { from the } \\
\text { School of } \\
\text { Medicine, Uni- } \\
\text { versity of } \\
\text { Texas, USA } \\
\text { who had com- } \\
\text { pleted } 4 \text { years } \\
\text { of the CAM } \\
\text { project }\end{array}$ & $\begin{array}{l}\text { The curriculum had included } \\
\text { multiple multidisciplinary } \\
\text { lectures, } \\
\text { workshops, electives and } \\
\text { structured rotations and ad- } \\
\text { ditional educational } \\
\text { activities. }\end{array}$ & $\begin{array}{l}\text { Integrated teach- } \\
\text { ing across } 4 \\
\text { years }\end{array}$ & $\begin{array}{l}\text { Two family } \\
\text { medicine phy- } \\
\text { sicians }\end{array}$ & & $\begin{array}{l}\text { Qualitative in-depth, face to } \\
\text { face, semi-structured interviews } \\
\text { - coded and thematically inter- } \\
\text { preted }\end{array}$ & $\begin{array}{l}\text { Very small } \\
\text { sample size } \\
\text { and interviewer } \\
\text { bias }\end{array}$ \\
\hline $\begin{array}{l}\text { Hassed } \\
2004^{30}\end{array}$ & $\begin{array}{l}\text { Undergraduate } \\
\text { medical stu- } \\
\text { dents at } \\
\text { Monash Uni- } \\
\text { versity, Aus- } \\
\text { tralia learning } \\
\text { integrated } \\
\text { CAM over the } \\
5 \text { year duration } \\
\text { of the medical } \\
\text { degree. }\end{array}$ & $\begin{array}{l}\text { Core curriculum teaching in- } \\
\text { cluding mindfulness-based } \\
\text { stress management pro- } \\
\text { grams, lectures and forums } \\
\text { on complementary medi- } \\
\text { cine, and integration into } \\
\text { weekly case-based teach- } \\
\text { ing. This covers principles, } \\
\text { research, evidence base, } \\
\text { ethics and clinical } \\
\text { applications. Additional op- } \\
\text { portunities to undertake op- } \\
\text { tional CAM } \\
\text { electives offered. }\end{array}$ & $\begin{array}{l}3 \text { day transition } \\
\text { camp with self- } \\
\text { care theme, } 2 \text { in- } \\
\text { troductory lec- } \\
\text { tures, } 6 \times 2 \text { hour } \\
\text { tutorials, } 2 \text { mind } \\
\text { body medicine } \\
\text { lectures, } \\
8 \text { hour CAM } \\
\text { teaching in sec- } \\
\text { ond year } \\
\text { Optional elec- } \\
\text { tive: } 12 \text { weeks } x \\
2 \text { hours }\end{array}$ & $\begin{array}{l}\text { Not } \\
\text { specified }\end{array}$ & $N / A$ & Nil & $\begin{array}{l}\text { Overview of } \\
\text { 'holistic' nature } \\
\text { of the medical } \\
\text { program lacked } \\
\text { student per- } \\
\text { spectives and } \\
\text { outcomes as- } \\
\text { sessment }\end{array}$ \\
\hline $\begin{array}{l}\text { Hoffmann and } \\
\text { Colleagues } \\
2019^{23}\end{array}$ & $\begin{array}{l}40 \text { first-year } \\
\text { medical } \\
\text { students at } \\
\text { University of } \\
\text { lowa Carver } \\
\text { College of } \\
\text { Medicine, USA }\end{array}$ & $\begin{array}{l}\text { The experimental group } \\
\text { viewed educational } \\
\text { videos and participated in } \\
\text { hands-on massage } \\
\text { practice } \\
\text { The control group only } \\
\text { viewed the educational vid- } \\
\text { eos. }\end{array}$ & $\begin{array}{l}\text { Hands on mas- } \\
\text { sage } x 11 \text { hours } \\
\text { and/or } \\
\text { Educational vid- } \\
\text { eos } \times 4 \text { hours, } \\
\text { over } 6 \text { week pe- } \\
\text { riod }\end{array}$ & $\begin{array}{l}\text { Two co- } \\
\text { course direc- } \\
\text { tors and five } \\
\text { current mas- } \\
\text { sage therapy } \\
\text { students }\end{array}$ & $1,2 a, 2 b$ & $\begin{array}{l}\text { WHO Quality of Life Bref Sur- } \\
\text { vey, 6-8 students from both } \\
\text { groups participated in post- } \\
\text { course focus groups, knowledge } \\
\text { assessment } \\
\text { using non-validated tools. Partic- } \\
\text { ipants completed } \\
\text { pre- and post-course assess- } \\
\text { ments of knowledge, } \\
\text { attitudes, and personal } \\
\text { wellness }\end{array}$ & $\begin{array}{l}\text { Small sample } \\
\text { size } \\
\text { Some non-vali- } \\
\text { dated assess- } \\
\text { ment tools }\end{array}$ \\
\hline $\begin{array}{l}\text { Jeffries } \\
2001^{31}\end{array}$ & $\begin{array}{l}\text { Unspecified } \\
\text { sample size of } \\
\text { medical stu- } \\
\text { dents from } \\
\text { Creighton Uni- } \\
\text { versity School } \\
\text { of Medicine, } \\
\text { USA }\end{array}$ & $\begin{array}{l}\text { Senior elective with lectures } \\
\text { and group discussions. In- } \\
\text { cluded conducting research } \\
\text { on CAM, a scientific evalua- } \\
\text { tion of efficacy, and a clini- } \\
\text { cal rotation. }\end{array}$ & $\begin{array}{l}4 \text { week } \\
\text { duration }\end{array}$ & $\begin{array}{l}\text { CAM practi- } \\
\text { tioners super- } \\
\text { vising clinical } \\
\text { rotation }\end{array}$ & 1 & $\begin{array}{l}\text { Post-course survey assessing } \\
\text { student satisfaction }\end{array}$ & $\begin{array}{l}\text { Unknown sam- } \\
\text { ple size } \\
\text { Lack of } \\
\text { pre-evaluation } \\
\text { Lack of } \\
\text { objective out- } \\
\text { come } \\
\text { measure }\end{array}$ \\
\hline
\end{tabular}




\begin{tabular}{|c|c|c|c|c|c|c|c|}
\hline $\begin{array}{l}\text { Karpa } \\
2012^{28}\end{array}$ & $\begin{array}{l}23 \text { fourth year } \\
\text { medical stu- } \\
\text { dents from } \\
\text { Pennsylvania } \\
\text { State Univer- } \\
\text { sity College of } \\
\text { Medicine, USA }\end{array}$ & $\begin{array}{l}\text { A herbal/natural product } \\
\text { course using classroom } \\
\text { presentations and active } \\
\text { learning mechanisms that } \\
\text { include experiential } \\
\text { rotations, case-based learn- } \\
\text { ing, and team-based learn- } \\
\text { ing. }\end{array}$ & $\begin{array}{l}40 \text { classroom } \\
\text { hours, and clini- } \\
\text { cal } \\
\text { rotations. The } \\
\text { course was car- } \\
\text { ried out } \\
\text { annually over } 3 \\
\text { academic years }\end{array}$ & $\begin{array}{l}\text { Pharmacol- } \\
\text { ogy } \\
\text { faculty } \\
\text { member, mul- } \\
\text { tidisciplinary } \\
\text { faculty mem- } \\
\text { bers and } \\
\text { guest } \\
\text { lecturers with } \\
\text { varied back- } \\
\text { grounds }\end{array}$ & $1 \& 2 a$ & $\begin{array}{l}\text { Final course grades } \\
\text { determined on the basis of } \\
\text { in-class presentations, } \\
\text { attendance, participation and } \\
\text { professionalism in class and } \\
\text { clinical rotations. } \\
\text { Likert-type questions and narra- } \\
\text { tive responses used to assess } \\
\text { student opinion of knowledge } \\
\text { and skills } \\
\text { imparted by the elective and } \\
\text { overall course content }\end{array}$ & $\begin{array}{l}\text { Limited enroll- } \\
\text { ment capacity } \\
\text { and scheduling } \\
\text { difficulties re- } \\
\text { ducing the } \\
\text { sample size } \\
\text { Inability to di- } \\
\text { rectly measure } \\
\text { the impact that } \\
\text { the course has } \\
\text { had on stu- } \\
\text { dent-patient in- } \\
\text { teractions in } \\
\text { clinical encoun- } \\
\text { ters }\end{array}$ \\
\hline $\begin{array}{l}\text { Laken and Co- } \\
\text { sovic } \\
1995^{26}\end{array}$ & $\begin{array}{l}\text { Seven medical } \\
\text { students elec- } \\
\text { tively enrolled } \\
\text { from Wayne } \\
\text { State Univer- } \\
\text { sity Medical } \\
\text { School, USA }\end{array}$ & $\begin{array}{l}\text { Senior elective delivered us- } \\
\text { ing didactic lecture, films, } \\
\text { first-hand experience and } \\
\text { observation of alternative } \\
\text { practitioners. Students ex- } \\
\text { plored hypnosis, chiroprac- } \\
\text { tic, therapeutic touch, medi- } \\
\text { cation, biofeedback, } \\
\text { acupuncture, homeopathy, } \\
\text { naturopathy, and } \\
\text { massage therapy. }\end{array}$ & $\begin{array}{l}7 \text { days of } \\
\text { formal } \\
\text { teaching } \\
1 \text { day observa- } \\
\text { tion clinical } \\
\text { placement }\end{array}$ & $\begin{array}{l}\text { Alternative } \\
\text { medicine } \\
\text { practitioners } \\
\text { in the Detroit } \\
\text { area }\end{array}$ & 1 & $\begin{array}{l}\text { Student evaluation of course } \\
\text { structure and } \\
\text { content }\end{array}$ & $\begin{array}{l}\text { Lack of objec- } \\
\text { tive assess- } \\
\text { ment of } \\
\text { knowledge }\end{array}$ \\
\hline $\begin{array}{l}\text { Lehmann } \\
\text { and } \\
\text { Colleagues } \\
2014^{35}\end{array}$ & $\begin{array}{l}30 \text { medical } \\
\text { students at the } \\
\text { Institute for } \\
\text { General Prac- } \\
\text { tice and Fam- } \\
\text { ily Medicine at } \\
\text { the Otto Von } \\
\text { Guericke Uni- } \\
\text { versity, Ger- } \\
\text { many }\end{array}$ & $\begin{array}{l}\text { Elective course involving in- } \\
\text { troductory lectures followed } \\
\text { by discussion, performance } \\
\text { of practical exercises, and } \\
\text { student presentations on a } \\
\text { self-chosen topic. Also } \\
\text { included a one day } \\
\text { excursion to the European } \\
\text { library for homeopathy (Ko- } \\
\text { then). }\end{array}$ & $\begin{array}{l}\text { Three weekend } \\
\text { course OR a } \\
\text { block course - to- } \\
\text { tal of } 56 \text { hours in } \\
\text { either form }\end{array}$ & $\begin{array}{l}\text { Conventional } \\
\text { medicine } \\
\text { practitioner }\end{array}$ & 1, 2a, 3 & $\begin{array}{l}\text { Semi-structured discussions for } \\
\text { a qualitative analysis. Topics in- } \\
\text { cluded experience of the semi- } \\
\text { nar, and anticipated use of ho- } \\
\text { meopathy in future practice. }\end{array}$ & $\begin{array}{l}\text { Voluntary par- } \\
\text { ticipation in an } \\
\text { optional sub- } \\
\text { ject may have } \\
\text { lead to less } \\
\text { critical, more } \\
\text { positive } \\
\text { results on the } \\
\text { survey, } \\
\text { Small sample } \\
\text { size of stu- } \\
\text { dents, bias }\end{array}$ \\
\hline $\begin{array}{l}\text { Ma } \\
\text { and } \\
\text { Colleagues } \\
2014^{36}\end{array}$ & $\begin{array}{l}251 \text { students } \\
\text { at a Chinese } \\
\text { Military Medi- } \\
\text { cal University, } \\
\text { China }\end{array}$ & $\begin{array}{l}\text { EBM course formally } \\
\text { included in the curriculum, } \\
\text { combining lectures with } \\
\text { small group } \\
\text { discussion and } \\
\text { student-teacher } \\
\text { exchange sessions. It } \\
\text { included } 5 \text { lectures and } 2 \\
\text { seminars. }\end{array}$ & 20 hour course & Faculty staff & $1 \& 2 a$ & $\begin{array}{l}\text { Pre and post training surveys } \\
\text { with comparisons of percentage } \\
\text { change of scores pre and post } \\
\text { training using } 6 \text { point Likert scale }\end{array}$ & \\
\hline $\begin{array}{l}\text { Mahapatra } \\
\text { and } \\
\text { Colleagues } \\
2017^{32}\end{array}$ & $\begin{array}{l}17 \text { students } \\
(33 \%) \text { in the } \\
\text { class of } 2015 \\
\text { and } 22 \text { stu- } \\
\text { dents }(42 \%) \text { in } \\
\text { the class of } \\
2016 \text { from } \\
\text { Mayo Clinic } \\
\text { School of } \\
\text { Medicine, USA }\end{array}$ & $\begin{array}{l}\text { A mandatory short I.M. cur- } \\
\text { riculum across all years of } \\
\text { medical school. Content fo- } \\
\text { cused on basic science and } \\
\text { experimental and evidence } \\
\text { based knowledge. }\end{array}$ & Not specified & $\begin{array}{l}\text { I.M. profes- } \\
\text { sionals and } \\
\text { physician fac- } \\
\text { ulty members } \\
\text { with expertise } \\
\text { in integrative } \\
\text { therapies. }\end{array}$ & $1 \& 2 a$ & $\begin{array}{l}\text { Paired data analysis of students } \\
\text { who completed two surveys in } \\
\text { their first and third year. Chi- } \\
\text { square test, Wilcoxon rank sum } \\
\text { test, McNamara agreement test, } \\
\text { signed rank test used. }\end{array}$ & $\begin{array}{l}\text { Lack of objec- } \\
\text { tive measure of } \\
\text { students } \\
\text { knowledge }\end{array}$ \\
\hline $\begin{array}{l}\text { Maharaj } \\
2010^{37}\end{array}$ & $\begin{array}{l}\text { Selective mod- } \\
\text { ules Retrieved } \\
\text { to } 24 / 160 \text { stu- } \\
\text { dents from } \\
\text { University of } \\
\text { the West In- } \\
\text { dies, Jamaica }\end{array}$ & $\begin{array}{l}\text { Assessing spiritual health } \\
\text { and an introduction to alter- } \\
\text { native medicine practices }\end{array}$ & Not specified & Not specified & 1 & $\begin{array}{l}\text { No formal evaluation, positive } \\
\text { responses expressed in writing } \\
\text { by students }\end{array}$ & $\begin{array}{l}\text { No formal eval- } \\
\text { uation of the } \\
\text { program }\end{array}$ \\
\hline $\begin{array}{l}\text { Owen } \\
\text { anLewith } \\
2001^{27}\end{array}$ & $\begin{array}{l}\text { Unspecified } \\
\text { number of un- } \\
\text { dergraduate } \\
\text { medical stu- } \\
\text { dents at } \\
\text { Southampton } \\
\text { University, } \\
\text { U.K. }\end{array}$ & $\begin{array}{l}\text { Optional modules address- } \\
\text { ing the issues raised by } \\
\text { CAM, and examining its evi- } \\
\text { dence base. Covered CAM } \\
\text { therapies included homeop- } \\
\text { athy, chiropractic, osteopa- } \\
\text { thy and acupuncture. } \\
\text { Additional local clinic at- } \\
\text { tachments in both NHS and } \\
\text { private practice }\end{array}$ & $\begin{array}{l}8 \text { session mod- } \\
\text { ule, repeated bi- } \\
\text { annually, over a } \\
3 \text { year period }\end{array}$ & Three doctors & $1 \& 2 a$ & $\begin{array}{l}\text { Subjective student questionnaire } \\
\text { with Likert-based format } \\
+ \\
\text { Written comments encouraged }\end{array}$ & $\begin{array}{l}\text { Lack of pre and } \\
\text { post interven- } \\
\text { tion knowledge } \\
\text { measure }\end{array}$ \\
\hline $\begin{array}{l}\text { Perlman and } \\
\text { Stagnaro- } \\
\text { Green } \\
2010^{24}\end{array}$ & $\begin{array}{l}\text { New Jersey } \\
\text { Medical } \\
\text { School at the } \\
\text { University of } \\
\text { Medicine and } \\
\text { Dentistry, USA }\end{array}$ & $\begin{array}{l}\text { Evolution of a complemen- } \\
\text { tary, alternative, and inte- } \\
\text { grative medicine course } \\
\text { with clearly stated core } \\
\text { competencies and goals. } \\
\text { The program included lec- } \\
\text { tures and demonstrations of } \\
\text { acupuncture and manipula- } \\
\text { tion. Included teaching } \\
\text { about appraising evidence } \\
\text { and the ethical issues }\end{array}$ & $\begin{array}{l}4 \text { year integrated } \\
\text { teaching }\end{array}$ & $\begin{array}{l}\text { Faculty mem- } \\
\text { bers with ad- } \\
\text { vanced train- } \\
\text { ing or } \\
\text { knowledge of } \\
\text { CAM, includ- } \\
\text { ing a faculty } \\
\text { member from } \\
\text { the local mas- } \\
\text { sage school }\end{array}$ & N/A & Not specified & $\begin{array}{l}\text { No formal eval- } \\
\text { uation of the } \\
\text { program }\end{array}$ \\
\hline
\end{tabular}




\begin{tabular}{|c|c|c|c|c|c|c|c|}
\hline & & $\begin{array}{l}\text { raised, and proposed a } \\
\text { clerkship in } 3^{\text {rd }} \text { and } 4^{\text {th }} \text { year. }\end{array}$ & & & & & \\
\hline $\begin{array}{l}\text { Tahzib and } \\
\text { Daniel } \\
1986^{25}\end{array}$ & $\begin{array}{l}\text { Unspecified } \\
\text { number of un- } \\
\text { dergraduate } \\
\text { medical stu- } \\
\text { dents at the } \\
\text { University of } \\
\text { Sokoto, Niger }\end{array}$ & $\begin{array}{l}\text { Lectures, tutorials, seminars } \\
\text { demonstrations of tech- } \\
\text { niques such as acupunc- } \\
\text { ture, practical exercises in } \\
\text { analyzing medicinal plants, } \\
\text { and supervised field visits to } \\
\text { high grade traditional medi- } \\
\text { cal practitioners. }\end{array}$ & $\begin{array}{l}90 \text { hours over } 6 \\
\text { years: } 60 \text { hours } \\
\text { of content, } 30 \\
\text { hours of clinical } \\
\text { placement }\end{array}$ & $\begin{array}{l}\text { Academic } \\
\text { medical staff, } \\
\text { visiting ex- } \\
\text { perts, schol- } \\
\text { ars from other } \\
\text { universities, } \\
\text { traditional } \\
\text { medical prac- } \\
\text { titioners }\end{array}$ & $\mathrm{N} / \mathrm{A}$ & Not specified & $\begin{array}{l}\text { No student } \\
\text { evaluation } \\
\text { Lack of objec- } \\
\text { tive knowledge } \\
\text { assessment }\end{array}$ \\
\hline
\end{tabular}

Likewise, the qualifications of CAM educators for such programs must be consistent and their repeated involvement sustainable. Whilst many programs utilised communitybased CAM practitioners ${ }^{25,26,31,35}$ difficulties in repeatedly sourcing appropriately qualified instructors were identified. ${ }^{21}$ Where faculty staff were involved in teaching, several programs were sustainable for longer. ${ }^{21,22,30}$ Whilst both CAM practitioners and faculty staff could both introduce an element of bias, this could be overcome with clear learning outcomes and an evidence-based teaching approach. In view of sustainability, it may be more appropriate to deliver teaching through faculty staff, some of who receive further training in EBM. Curriculum developers should consider and account for the additional cost of incorporating CAM programs within UGME.

\section{Appropriate assessment and educational outcomes}

Few of the programs performed formalised pre and/or postcourse student assessment or evaluation as a measure of the change in knowledge. This reaffirmed findings from Stratton and Colleagues ${ }^{3}$ which reported the same observation in the programs receiving CAM education grants from the NCCAM. Instead, general qualitative statements were regarded as a measure of overall student satisfaction and increased knowledge. ${ }^{21,27,34}$ Student reactions and knowledge (Kirkpatrick's Level 1, 2a, 2b) were the most commonly achieved outcomes, with student knowledge measured subjectively through student questionnaires. ${ }^{22,27-29,31,32}$ Whilst Frenkel and Colleagues ${ }^{34}$ was successful in determining the willingness of learners to apply new knowledge and skills (Kirkpatrick's' Level 3 outcome), it was the only study to do so. Course designers within medical schools must create educational programs that aim to directly impact patient care, rather than increasing knowledge without a foreseeable change to clinical practice. This is an undoubtedly challenging task, particularly since many widely taught CAM therapies have not yet been proven efficacious by scientific standards. For medical educators to educate appropriately, an evidence base for positive patient outcomes must first be established.

\section{Limitations}

Articles may have been omitted due to the adopted search strategy, inclusion criteria, and limit of English language articles only. Grey literature was not performed. Several programs were incompletely reported, potentially influencing the outcomes reported in this review. Many medical school faculty and Deans who were approached did not participate, leading to potential selection bias. Studies incorporating face-to-face interviewing may also be subject to observation bias. A small sample size, apparent in several studies, could also reduce the power and, therefore, reliability of results. Post-evaluations using subjective qualitative Likert-based assessment do not provide an objective measure of program success, particularly where students' results cannot be compared to pre-program standards. As only the first three levels of Kirkpatrick's Hierarchy were reached, the patient implications of CAM in UGME could not be determined. No studies reported on the change in patient outcomes or healthcare delivery (Kirkpatrick's Level 4). Longitudinal prospective studies would provide curriculum developers with insight to the real-world effects of CAM education, where patient outcomes can be correlated to teaching interventions. Several studies did not report outcomes of interest, such as teaching duration, disciplines and teaching staff. ${ }^{22,27,28,31,32,37}$

\section{Conclusions}

The aim of this review was to evaluate the various approaches for teaching CAM in UGME. Despite various limitations, it is apparent CAM teaching is inconsistently incorporated into medical schools at a multi-national level. The diversity in approaches reflects the lack of defined graduate competencies as they relate to this specific area. With a breadth of CAM disciplines and an array of teaching and learning approaches, there is no single recommended education program that has been demonstrated to produce positive patient outcomes. Although the concept of an EBM course appeals as a potential solution to overcoming the enormous breadth and content developments in CAM, ultimately there is a deficiency of evidence to demonstrate the real-life healthcare impact. Curriculum developers would be better guided with further research, aligning health outcomes with teaching, assessment and evaluation of proposed CAM programs. 


\section{Conflict of Interest}

The authors declare that they have no conflict of interest.

\section{References}

1. National Centre for Complementary and Integrative Health. Complementary, alternative, or integrative health: What's in a name? 2018. [Cited 21 July 2020]; Available from: https://www.nccih.nih.gov/health/complementary-alternative-or-integrative-health-whats-in-a-name.

2. Yamey G. Can complementary medicine be evidence-based? West J Med. 2000;173(1):4-5.

3. Stratton TD, Benn RK, Lie DA, Zeller JM, Nedrow AR. Evaluating CAM education in health professions programs. Acad Med. 2007;82(10):956-61.

4. Quartey NK, Ma PH, Chung VC, Griffiths SM. Complementary and alternative medicine education for medical profession: systematic review. Evid Based Complement Alternat Med. 2012;656812.

5. Bates R. A critical analysis of evaluation practice: the Kirkpatrick Model and the principle of beneficence. Evaluation and Program Planning. 2004;27:341-7.

6. Kirkpatrick DL, Kirkpatrick JD. Kirkpatrick's four levels of training evaluation. Alexandria, VA: ATD Press; 2016.

7. Ragsdale J, Berry A, Gibson J, Herber-Valdez C, Germain L, Engle DL, et al. Evaluating the effectiveness of undergraduate clinical education programs. Med Educ Online. 2020;25:1.

8. Tricco AC, Lillie E, Zarin W, O'Brien KK, Colquhoun H, Levac D, et al. PRISMA extension for scoping reviews (PRISMAScR): checklist and explanation. Ann Intern Med. 2018;169:467-73.

9. Brinkhaus B, Witt CM, Jena S, Bockelbrink A, Ortiz M, Willich SN. Integration of complementary and alternative medicine into medical schools in Austria, Germany and Switzerland--results of a cross-sectional study. Wien Med Wochenschr. 2011;161(1-2):32-43.

10. Brokaw JJ, Tunnicliff G, Raess BU, Saxon DW. The teaching of complementary and alternative medicine in U.S. medical schools: a survey of course directors. Acad Med. 2002;77(9):876-81.

11. Kim DY, Park WB, Kang HC, Kim MJ, Park KH, Min BI, et al. Complementary and alternative medicine in the undergraduate medical curriculum: a survey of Korean medical schools. J Altern Complement Med. 2012;18(9):870-4.

12. Rampes H, Sharples F, Maragh S, Fisher P. Introducing complementary medicine into the medical curriculum. J R Soc Med. 1997;90(1):19-22.

13. Sampson $W$. The need for educational reform in teaching about alternative therapies. Acad Med. 2001;76(3):248-50.

14. Smith KR. Factors influencing the inclusion of complementary and alternative medicine (CAM) in undergraduate medical education. BMJ Open. 2011;1(1):e00074.

15. Varga O, Marton S, Molnar P. Status of complementary and alternative medicine in European medical schools. Forsch Komplementmed. 2006;13(1):41-5.

16. Chitindingu E, George G, Gow J. A review of the integration of traditional, complementary and alternative medicine into the curriculum of South African medical schools. BMC Med Educ. 2014;14:40.

17. Ruedy J, Kaufman DM, MacLeod H. Alternative and complementary medicine in Canadian medical schools: a survey. CMAJ. 1999;160(6):816-7. 18. Tsuruoka K, Tsuruoka Y, Kajii E. Complementary medicine education in Japanese medical schools: a survey. Complement Ther Med. 2001;9(1):28-33.
19. World Health Organization. Factsheet 134: Traditional Medicine. 2013. [Cited 23 July 2020]; Available from: https://apps.who.int/gb/ebwha/pdf_files/EB134/B134_24-en.pdf.

20. Hollenberg D, Zakus D, Cook T, Wei X. Re-positioning the role of traditional, complementary and alternative medicine as essential health knowledge in global health: do they still have a role to play? World Health Popul. 2008;10:62-75.

21. Bailey ML, Chudgar SM, Engle DL, Moon SD, Grochowski CO, Clay AS. The impact of a mandatory immersion curriculum in integrative medicine for graduating medical students. Explore (N.Y.). 2015;11(5):394-400.

22. da Silva JB, Saidah R, Megid CB, Ramos NA. Teaching acupuncture to medical students: the experience of Rio Preto Medical School (FAMERP), Brazil. Acupunct Med. 2013;31(3):305-8.

23. Hoffmann DS, Dancing D, Rosenbaum M. Massage and medicine: an interprofessional approach to learning musculoskeletal anatomy and enhancing personal wellness. Acad Med. 2019;94(6):885-92.

24. Perlman A, Stagnaro-Green A. Developing a complementary, alternative, and integrative medicine course: one medical school's experience. J Altern Complement Med. 2010;16(5):601-5.

25. Tahzib F, Daniel SO. Traditional medicine and the modern medical curriculum. Lancet. 1986;2(8500):203-4.

26. Laken MP, Cosovic S. Introducing alternative/complementary healing to allopathic medical students. J Altern Complement Med. 1995;1(1):93-8.

27. Owen D, Lewith GT. Complementary and alternative medicine (CAM) in the undergraduate medical curriculum: the Southampton experience. Med Educ. 2001;35(1):73-7.

28. Karpa K. Development and implementation of an herbal and natural product elective in undergraduate medical education. BMC Complement Altern Med. 2012;12:57.

29. Forjuoh SN, Rascoe TG, Symm B, Edwards JC. Teaching medical students complementary and alternative medicine using evidence-based principles. J Altern Complement Med. 2003;9(3):429-39.

30. Hassed CS. Bringing holism into mainstream biomedical education. J Altern Complement Med. 2004;10(2):405-7.

31. Jeffries WB. A fourth-year elective course in alternative medicine. Acad Med. 2001;76(5):525-6.

32. Mahapatra S, Bhagra A, Fekadu B, Li Z, Bauer BA, Wahner-Roedler DL. Incorporation of integrative medicine education into undergraduate medical education: a longitudinal study. J Integr Med. 2017;15(6):442-9.

33. Hasler D, Leggit JC. Complementary and integrative health education in the medical school curriculum: an interest survey. Med Acupunct. 2018;30(6):298-307.

34. Frenkel M, Frye A, Heliker D, Finkle T, Yzaguirre D, Bulik R, et al. Lessons learned from complementary and integrative medicine curriculum change in a medical school. Med Educ. 2007;41(2):205-13.

35. Lehmann B, Kremer B, Werwick K, Herrmann M. Homeopathy as elective in undergraduate medical education-an opportunity for teaching professional core skills. GMS Z Med Ausbild. 2014;31(1):Doc7.

36. Ma X, Xu B, Liu Q, Zhang Y, Xiong H, Li Y. Effectiveness of evidencebased medicine training for undergraduate students at a Chinese Military Medical University: a self-controlled trial. BMC Med Educ. 2014;14:133.

37. Maharaj SR. Preparing medical graduates to practise in a changing environment: complementary/alternative medicine in the medical undergraduate curriculum of the University of the West Indies. West Indian Med J. 2010;59(3):284-6

38. Akinola OB. Should complementary and alternative medicine familiarisation modules be taught in African medical schools? Zhong Xi Yi Jie He Xue Bao. 2011;9(11):1165-9. 